\author{
Marina Kotova (iD) https://orcid.org/0000-0002-0861-8652 \\ Petersburski Uniwersytet Państwowy \\ mariyur@mail.ru \\ Daria Lakomova (iD) https://orcid.org/0000-0002-6036-5082 \\ Petersburski Uniwersytet Państwowy \\ dara.lakomova@yandex.ru
}

\title{
Stylistic features of the surrealistic experimental prose of Věra Linhartová
}

\begin{abstract}
The article illustrates specific stylistic features of Verra Linhartová's late prose, written in the Czech language during the period of her cooperation with the Prague surrealist group from 1962 to 1965 . We focus our attention on the style-forming potential of different syntactic structures, code-switching and intertext, explaining their relation to the author's poetics and the surrealist tradition.
\end{abstract}

Keywords: Czech surrealism, syntax, multilingualism, intertextualiy, Linhartová

\section{Introduction}

The literary creativity of Věra Linhartová can hardly be given a clear and unambiguous definition. The peculiarity of her creative approach goes beyond mere literature. The texts of Linhartová are a laboratory, in which an experiment on the Czech language is carried out. The author tries to find the limits of the language's expressive ability, the place where the language is no longer able to convey objective reality. The text is a clear reflection of the structure of the language system, which has its own internal rules and restrictions. The German literary scholar Professor Anya Tippner argues that the creative method of Linhartová is based on the principle of language play (Tippnerová, 2014: 245). This concept was introduced by L. Wittgenstein, implying that language itself is capable of constructing reality in the mind of the speaker, and the word acquires its meaning only at the moment of speaking. Similarly, the texts of Linhartová are lined up as if by themselves, some language units affect others, setting further language moves. 
Verra Linhartová is the author of five collections of works of fiction, which were published from 1964 to 1968: "Meziprůzkum nejblíž uplynulého" [Interstudy of the Recent Past] (1964), "Prostor k rozlišení" [The Space for Recognition] (1964), "Rozprava o zdviži" [A debate about the Lift] (1965), "Přestořeč" [Still the speech] (1966) and "Dům daleko" [The House is Far] (1968). Most often, the name of the writer appears in connection with her activities in the Prague group Surrealistická skupina, of which she was a member from 1962 to 1966 . After the events of 1968, Linhartová emigrated to France and ceased to write in the Czech language. Among the whole Czech surrealist movement, Linhartová stands apart largely because of her more individualistic approach to creativity.

The experimental texts of Věra Linhartová, written during her work with the group of Prague surrealists, are among the most interesting and insufficiently studied phenomena of Czech literature. In this article, we will discuss five texts written from 1962 to 1965: "Meziprůzkum nejblíž uplynulého" [Interstudy of the Recentt Past] (August-December 1962) and "Pikareskní průmět na pozadí" [Against the background of the picaresque projection] (December 1962-April 1963), published in Meziprůzkum nejblíž uplynulého; "Dům daleko" [The House is Far] (October 1963-March 1964), "Ubývání hlásky 'm”" [Fading of the sound 'm'] (May-August 1964) and "Přehledné uspořádání" [Visual Ordering] (March-June 1965), published in Dům daleko.

This was the final stage of the Linhartová's Czech literary-language experiment in which her poetics, along with the ideas and techniques of surrealism, were vividly embodied.

The purpose of the study was to identify the stylistic features of selected texts. Our focus was on language elements from three different areas: syntax, multilingualism and intertextuality. They were considered from the point of view of style-forming potential, one way or another embodied in each of the texts reviewed. In the course of the study, we were able to determine the patterns of appearance of certain elements in the texts, their functions within the poetics of the writer, and also to draw conclusions about the influence of the surrealistic environment on the author's approach to the creation of her works.

\section{Syntax}

All the texts we are considering are in their content close to the inner monologue, the stream of consciousness of the narrator.

In addition, they are heterogeneous in structure: a fragmentary, plotless narrative is mixed with elements of reasoning, which, as it were, follow each other according to the principle of association. The text seems to be on the move, as in a natural spontaneous stream of thoughts. Thus, it becomes necessary to consider the issue of the relationship between the written and the oral in the texts of Linhartová.

This relationship interests us, first of all, from the point of view of one of the central motifs of the experimental prose of Věra Linhartová speech as a means of constructing and approving the world around us. The form of existence of the text, that is, its oral or written nature, is one of the objective factors affecting, among other things, the syntax 
of the statement. There are no clear boundaries between oral and written speech, and in linguistics the question of their relationship is open, since both these forms are capable of influencing each other.

One of the main features of oral speech can be called the spontaneity of statement that can also be embodied in individual examples of writing (for example, in personal diaries) (Machová, 2008: 314-315).

The texts published in different collections are heterogeneous in their syntactic structure. All the texts, at first glance, are built in the form of an internal monologue. However, for example, the very first text in chronology entitled "Meziprůzkum nejblíž uplynulého" can be interpreted as a diary entry transferred to a printed format for several reasons. Here there are fragments reflecting the objective reality of the narrator: the events of her past and the description of her surrounding reality in the present. The diary form manifests itself in the syntax in the inserted constructions, highlighted in the text by brackets, as, for example, in the following fragment: (Škrtnuty tři odstavce: o predzjednaném zásahu do skutečnosti a o utrpení, který mi tento postup způsoboval u osoby, kterou jsem pred časem málem miloval.) (Meziprůzkum nejblíž uplynulého, p. 160) [Three paragraphs are deleted: about intervention into reality by prior agreement and on torment which provoked this approach in a person who I almost loved before.] By content, we understand that this insertion is intended to reflect the written nature of the text, to convey by language means that in the original record is transferred graphically - the deleted text. We learn that these notes belong to the narrator due to the personal form of the auxiliary verb in the predicate jsem miloval. Moreover, there is an ellipse uncharacteristic of book speech, but natural for notes: the predicate including a passive participle requires the link-verb byt, which we do not observe here. The absence of a verb supposedly fixes the static nature of this component: the stream of thoughts of the narrator stops here to describe the text itself. Thus, we understand that the nature of the text which is before us is more complicated than it seems at first glance. The inserted constructions, given in brackets, serve as a hint to the reader for correct text perception. Otherwise, syntactically, this text is not as remarkable as the following four. It can be said that at this very moment a peculiar interpretation of the creative approach takes place, stylistically the texts become noticeably more complicated.

From the very first pages, the text under the title "Pikareskní průmět na pozadí" surprises with the complexity of the syntax due to the appearance of a large number of metalanguage comments through which the narrator searches for the expressive boundaries of the language. All this requires a sequence of presentation, which is reflected in the abundance of complex sentences with all sorts of adverbial and conditional subordinate clauses. To create a conditional situation, the subjunctive mood of verbs is often used as a predicate. So, in one of the passages, the narrator seeks to define herself: Protivim-li se sama sobě k zániku, tedy jsem na konci. Jsem-li na konci, tedy jsem, poněkud tedy jsem. Myslím-li si, že nejsem, jsem-li na konci, je na tom tedy něco skutečného, ne všechno, když vlastně jsem a přitom myslím, že nejsem - něco v̌̌ak na tom je, a tedy poněkud nejsem. (Meziprůzkum nejblíž uplynulého, p. 171) [If I become deadly nasty to myself, then I'm close to the end. If I am at the end, then I am, to some extent I am. If I think that I am not, if I am at the end, it means that there is something real in it, not everything, since at the 
same time I think that I am not - something is still in it, and it means to some extent I am not.] This short excerpt is taken from a chain of logical judgments, in which jsem then transforms into the forms jsouc, byla jsem, budu, the personal form jsem itself and the negative form nejsem are repeated several times. The jumble of forms of the verb byt, however, does not in the least impede the perfect grammar of this passage, which ends with the words: Nevedu tedy řě o sobě nebo o něčem, vedu řeč, kterou se stávám. Stanu se sebou, stanu-li řečí. Jsem řečí. (Meziprůzkum nejblíž uplynulého, p. 171) [So, I am not talking about myself or something, I am talking about becoming one. I will become myself if I become speech. I am Speech.] The narrator identifies herself with speech, therefore, the abundance of various forms of the verb byt relating to her, illustrates the main idea of Linhartová's literary creativity - the study of language boundaries. Language is a complex system that is realized in speech, and in this passage complex structures appear as a metaphorical image of this system. In the same vein, we can judge the other passages that demonstrate language transformations.

In the texts of the collection "Dům daleko" there is a constant connection between the syntax and the content of the statement. In those passages where the description of the surrounding reality, events or self-description of the subject takes place, the syntax is noticeably simplified. These are mostly simple sentences, often nominal one-component ones: "Proměna nezničitelnosti."'[Change of indestructibility.]; "Sledost dani." [Sequence of return.]; "Krouživec." [Turning.]; "Den plesu." [The day of the ball.]. There is also a tendency to omit the link-verb být in nominal predicates: "Mé oči sedmiramenné lustry." [My eyes seven-branch chandeliers.]; "Krov domu na mých ramenou." [The rafters of the house on my shoulders.]; "Obrazy pohnutě tekuté.” [The images alarmingly fluid.]; "Tep pramének." [The pulse a trickle.]. Firstly, the method of omission of the link-verb gives a shade of vividness to speech. Secondly, it brings the sentence closer to the structure of a nominal one-component sentence.

The narrating subject tries to place the reality surrounding her in structures which could convey the very moment of the utterance as precisely as possible, express the momentary static image with language means, because in the next instant the surrounding reality will change together with the subject herself. All this corresponds to Linhartová's creative point of reference - a language play in which special language elements create an intra text reality. Among the features of the syntax of oral speech, O. Müllerová refers to the incomplete realisation of syntactic constructions, the insufficiently accurate designation of relations between parts of a sentence, and the lack of clarity of the boundaries between sentences. (Müllerová, 1994) Thus, it can be said that the texts of the collection are really approaching the fixation of spontaneous inner speech, which resembles one of the main techniques of the surrealists - automatic writing. This technique is determined by the desire to fix the natural flow of thoughts, to circumvent the censorship of consciousness. Let's clarify that the term "writing" defines the resultant only formally, meaningfully, they are close to oral speech, pronouncing a thought.

With fragments relating to reasoning about abstract phenomena, the situation is different. This is observed in all the texts of the collection Dim daleko, but to the greatest extent is revealed in the last text, entitled "Přehledné uspořádání". The syntactic structures here 
are mostly complicated, but consistent and logical. Let's consider one of the fragments: Ještě však bychom mohli odložit boty, ale protože během času nepochýbně ztratíme mnohem víc, nemusime ani těchto odložených bot litovat; a protože běh času, ostatně, neni tím pravým slovem, které by vystihovalo zmíněnou mnohoměrnost a návratnost zdejši rozlohy, zůstanou naše boty stejně v tom mistě, kde jsme je opustili, a můžeme se pro ně kdykoli vrátit: vždycky je nalezneme. (Di̊m daleko, p. 74) [But in general, we could still take off our shoes, but due to the fact that with the flow of time we will undoubtedly lose much more, we don't even need to feel sorry for the shoes taken off; and because the flow of time, generally speaking, is not the exact word that reflects the multidimensionality and repeatability of the local area, our shoes will remain in the same place where we left them, and we can return for them anytime: we will always find them.] This complex sentence includes nine simple ones, here you can find both coordinate and subordinate cohesion. The structure of this sentence is logical and similar to the theorem: in the first main clause, a thesis is given, then its proof follows, and in conclusion it is as if the above statement were generalised. Such interpretation is suggested to us by the text itself, which from the very first page abounds with the lexicon from the field of geometry: pravoúhly prostor [rectangular space], počáteční bod [starting point], úhlopř́čka [diagonal], prüměr [diameter], etc. According to the definition given by T.E. Anikina, "a title is a kind of spring into which the text of an artistic whole is folded," it is the key that helps to decode the text." (Anikina, 2012: 6) So, one more clue to the interpretation is hidden in the title of the text, "visual ordering", which in some sense can characterise the geometry, which in its essence is a visual setting the surrounding reality in order.

Thus, through the complicated syntax, this "spring" of the title is unfolded, which sets the modus of interpretation of the text.

Returning to the subject of correlation of the oral and written in the texts of Linhartová, one cannot fail to mention the inconstancy of the narrator. It is expressed in the fact that the grammatical category of the gender of nominal predicates, verbal predicates in the form of the past tense conditional, as well as in the coordinate attributes, changes with the development of the text. That is, in different parts of the same text, a sort of transformation of the narrating subject takes place. In addition, appeals to a certain subject appear, which are expressed in the presence of forms of the $2^{\text {nd }}$ person singular and plural. We see the following, for example, in the text Dům daleko: Ó, ano, ř́kám, uméní je mlčení. Souhlasím. Mlčíšs. Křičím: ó, ano, uměni neje kromě mlčení, jestliže mlčíš. Mlčíšs. Souhlasíś bez milosti. (Di̊m daleko, p. 29) [Oh, yes, I say, art is silence. I agree. You are silent. I shout: Oh, yes, there is no art except silence, since you are silent. You are silent. You ruthlessly agree.] The main feature of this passage is the emergence of the I-You dichotomy through the vicinity of the $1^{\text {st }}$ and $2^{\text {nd }}$ person forms. This suggests the presence of the traces of a dialogue here, or at least confirms the presence of the interlocutor. That is, in simplifying the syntax, it is possible to see here the formal designation of the transition from monological to dialogical speech.

In later texts the tendency to violation of language norms is traced, which should also be considered as a stylistic means. Cases of such violations in the collection Meziprĩzkum nejbliž uplynulého are sporadic, and they were discussed earlier. The collection 
Dim daleko turned out to be much richer in such elements. The most frequent were violations of the linguistic norms of the following nature: 1) omitting the indirect object after the preposition: "Nejinak lze plynout s." [No other way you can flow out.], "Své skutky nevztahuji k. " [I do not refer my actions to.]; 2) the use of negative pronouns and conjunctions with the sentence parts which do not presuppose negation: "Nic opakuje." [Nothing repeats], “... je možno neprejit ani obejit'” [... possible neither to pass through, nor to bypass ]; 3) omission of the link-verb být in nominal predicates; 4) the incorrect formation of negative forms of the link-verb byt: „, Nevim, zda neje tento dim ... " [I do not know if this house (does not) exist(s)]. This phenomenon can be viewed as an expression of scepticism about the ability of the language to reflect reality, and the continuity of the tradition of surrealism. The French surrealist poet Louis Aragon in his "Treatise on Style" [Traité du style] (1928) suggested abandoning the framework of spelling rules, syntax, punctuation, because their observance infringes on the free state of mind, which the surrealists sought to express in their creativity (Andreev, 2004: 102).

The text "Ubývání hlásky ' $\mathrm{m}$ "” is devoid of the usual punctuation system. There are no punctuation marks in it, the punctuation system is represented by only two symbols: a wide space and a wide space followed by a capital letter. On the whole, this system does not make it difficult to understand what is written, but the lack of final punctuation significantly affects the perception of the text. This is important because traditional punctuation serves not only to delimit sentences and designate homogeneous parts of the sentence, but also carries additional information about the communicative modality of the utterance (in other words, the purpose of the utterance) (Sedláček, 1986: 125). Punctuation in writing is entity, which prompts the recipient the correct interpretation of what has been read (let us recall the fateful role of a comma in the sentence about execution and pardon) and represents a kind of boundary. In oral speech, the accuracy of the transferred information is realized through intonation, pauses. When reading Linhartová's text, we also reflexively pause for longer spaces. Neglecting punctuation marks that are natural to writing is an attempt to approach the natural situation of an internal monologue. There is also a clear connection with the favourite method of the French (and later Czech) surrealists - automatic writing. Let us recall the call of L. Aragon once again. So, for example, in the poem by T. Tzara "The Approximate Man" [L'homme approximatif] (1925-1930) the stream of thought is not blocked by punctuation marks at all (Andreev, 2004: 224-225).

\section{Multilingualism}

The text as a communicative unit basically implies the use of one language. At the sudden appearance of at least one of the elements that are alien to this language, the codes are switched, i.e. a situation in which more than one language is actively used in an utterance, and the basic and included languages are differentiated (Lanstyák, 2000: 1-2).

In the second block of the stylistic features of Linhartová's later texts we can distinguish the appearance of foreign-language insertions. Mixing of multilingual elements in speech acts is manifested in the texts of Verra Linhartová at different levels: a lexeme, a sentence, 
a component of semantics. In addition, each of these elements appears in a specific context and follows from the preceding linguistic units, or sets the appearance of the subsequent ones. R. Pytlik notes that the initially set topic can be transformed into the most diverse and sometimes accidental motives; therefore it is sometimes difficult to predict how the statement will end (Pytlík, 1969: 165-166). In particular, as a consequence of such a "model" of text development, markers of other languages are woven into the text as one of the links in the chain of associations. Despite Linhartová's inclination to metalanguage comments explaining the choice of the used language means, the appearance of foreign language insertions is explained in detail very rarely. Instead, Linhartová leaves a kind of clue to decoding foreign elements.

In the texts we have chosen, passages are repeatedly encountered, where, next to a foreign language lexeme, its full equivalent in Czech is given. Such a technique is usually designated as intertext translation, that is, duplication of lexemes of the same semantics, but different in their language. The one that is given in the included language expresses the formal aspect of the utterance and is a representation of the "alien" category. The lexeme in the basic language serves to disclose the plan of contents. Introducing an intertext translation presupposes in advance a certain distance between the addressee and the included language, since there is a need for translation (Mareš, 2003: 26-27). We can observe such an explanatory model in the following passage: Neopakuje nevrací. Nadchází. Umírněné nesmírené témže tíše plyn̆. Revenant. Přizrak znovuvzkříšený. (Dům daleko, p. 35) [Does not repeat, does not return. It is coming. Moderate not reconciled by the same quietly follow. Revenant (from Fr. Ghost / newly returned). The ghost is again resurrected.] The French lexeme revenant is adjacent to the original Czech prizrak, and their meanings are the same - 'phantom, ghost'. In a sense, an additional interpretation here is suggested to us by the attribute znovuvzkríšený with the meaning 'newly resurrected', because the noun revenant is homonymous to the participle form of the verb revenir - 'to return again'. In this case, it is felt that the French insertion gives impetus to the creation of further associative series; here it embodies a constructive function. Moreover, it opens up the possibility of word creation, reveals the creative potential of the Czech language, since the lexeme znovuvzkríšený in joined-up writing is the result of interference, an attempt to convey the semantics of the French prefix re- with the meaning of repetition using the Czech language. Additional religious connotation also appears.

There are examples of the transformation of the lexemes themselves in the included language, the play goes beyond the Czech language alone: Jsem v bezjmenném stavu. Moje mínění někde setrnulo, zatímco jsem je opustil, lassen, ale jsa las-lasse, unaven. Las-situde-lassen. (Meziprůzkum nejblíž uplynulého, p. 177) [I'm in a nameless state. My opinion was numb while I left it, lassen (from German to leave), but being las-lassen (,, las “ from Fr. tired), tired. Las-situde-lassen.] This passage reflects the above-described principle of intertext translation: the German lassen and the Czech opustit are related by the common meaning 'leave'. This is the first code switch followed by the transformation of the included lexeme: the first syllable doubles, which, when separated by a hyphen, gives an impetus to the association and the next code change. Next, we identify the switch from German to French, since the Czech lexeme unaven is given, meaning 'tired', as 
well as the French las. The two included languages seem to be reconciled, merge into a complex form of las-situde-lassen, in which the Latin word lassitudo 'fatigue' can be guessed. Thus, in one short passage the whole four languages are included, that is, four codes, to which the similarity of pairs of languages on the basis of the phonetic and/or genetic proximity of the elements of the included languages leads. At the same time, all the transformations, except the final form, are accompanied by Czech equivalents. The basic language in terms of the disclosure of its potential here, rather, remains on the sidelines and acts as a commentary, simplifying the process of understanding what is happening. The very process of formation of such a complex chain of insertions resembles a game in which various associations enter, and the next language course depends on the previous one. It occurs by no means in a random order: the first switching of the code was based on the phonetic similarity of the elements of the two lexemes, and the second - on the continuity of the French language in relation to Latin. The order and following the rules are one of the main criteria for determining the play (Huizinga, 1997: 27-31). The play, in turn, along with dream, humour and imagination, is one of the basic concepts in the framework of Czech surrealism.

Switching of the code at the level of whole sentences is found only in the text "Ubývání hlásky 'm"'. A remarkable feature of this text, as we remember, is the complete absence of punctuation marks. A stream of speech is created in which the speaking subject from the Czech language organically and freely floats into the speech space constructed by a foreign language. Babylónie Můj sen zmateni jazyků Je-li někde řeč která by méla skladbu odlišnou od všech které znám Prastará Prostá Hluchavko Un rumeur surgit soudain de ce silence (Diom daleko, p. 44) [Babylon My dream confusion of languages Is there a speech somewhere which would be arranged not as all those that I know Ancient Simple Deaf nettle Un rumeur surgit soudain de ce silence (from Fr. Suddenly among this silence some hum is heard)]

The explanation for why the subject suddenly passes to French is given in this passage. Firstly, the image of Babylon appears, referring to the biblical legend of the first city and the confusion of languages. That is, the mixture of Czech and French given here is set by interpreting the cultural tradition; there is as if a reconstruction of the plot of the legend in the intertext space. Secondly, a dream motif is introduced, which implies a break with reality, liberation from the confining framework of consciousness and the power of the subconscious. In this context, the possibility of such an easy transition between two languages can be interpreted as the subject's will, literally immediately embodied in speech. Although within the framework of Linhartová's poetics, as we found out earlier, this circumstance acts only as the removal of conventional restrictions, since it is not reality that determines language, but language creates reality.

At the same time, the emergence of this motif connects Linhartová's creativity with the tradition of surrealism. Dream is one of the key motifs that appear in the creative paradigm of surrealism from its very origins. Since the 1960s in the Czech avant-garde environment, this topic is especially actualized, the technique of dream recording rooted in Freud's theory and the sphere of psychoanalysis extends. We see that this passage in its form and content just realizes this technique. 
The statement itself is in French, and, as in the case of foreign lexemes, follows from the previous context on the principle of association. Etymologically, the name of the plant hluchavka goes back to the word hluchy' with the meaning 'deaf', hence the motive of silence. The sudden hum continues the theme of Babylon. We do not encounter the intertext translation here, only separate semantic components are intertwined.

Further, the text continues the development of the biblical theme, and in this insertion it is impossible to discern an element that initiates further semantic branches. However, it is indisputable that switching the code marks a certain change inside the text: reality passes into a dream, silence passes into hum.

In the text there are five cases of such voluminous insertions, and each of them marks a certain change. So, we can say that switching the code in this case serves as a marker of some change. This may be a change in the intertext reality or the self-perception of the narrating subject.

It is also indicative that such a cluster of whole phrases in the included languages is found precisely in the text, where there is a reference to the legend of the Babylonian crowd. Here, foreign-language elements act as a kind of illustration, the context itself presupposes their appearance. It is indisputable that the reader must have sufficient language competence to perceive these elements; accordingly, this complicates the texts, narrowing the readership to which all the meanings laid down by the author will open.

In the same section, we will consider borrowings as a vocabulary resulting from the language contact of two or more languages. In the texts under consideration we encounter such situations of choice between two lexemes according to the following model: one of the options is borrowing from another language, the other is the native Czech lexeme, the selection process itself is accompanied by a comment about their compliance with the plan: Různé jazyky, různá slova: ̌̌eknu-li realita, nemohu nemyslet věc; řikám-li skutečnost, nemohu nemyslet skutek. Totéž dvojí. Realita hromaděni věci skutečnost učinění. (Meziprůzkum nejblíž uplynulého, p. 180) [Different languages. different words: if I say reality, I can thelp but think about a thing; if I say actuality, I cannot help thinking about action. It is the same. Reality is an accumulation of things, actuality is performing actions.] This passage tells about the difference of lexemes that are synonymous in the Czech language: the borrowed word realita and the original word skutečnost. There is a statement that these are different words from different languages, but none of them is perceived as alien. Interpretation is given on behalf of the subject herself, on the basis of her own associations. With the help of such a comparison - borrowed and original (with a clear idea of these two categories) - self-identification occurs with each of the halves. In addition, the imperfection of both forms of expression is expressed, some of their inferiority, which is compensated by their coexistence. Meta-language comments dispute the fact that these lexemes are synonyms, revealing differences and shades of meanings. There is a view on the language from the inside, which is typical of Linhartová's poetics. So, only the lexeme component fits into the question of multilingualism.

There is also an explanation of some borrowed lexemes due to the opacity of their internal form to avoid discrepancies: Sám smysl slova „, rezignace“ znamená, že pro věc, kterou jsme opustili, zpovzdálí necháme jenom presnějši výraz. (Meziprůzkum nejblíž 
uplynulého, p. 153) [The very sense of the word "refusal" means that for the thing that we left behind, we leave only a more precise expression.] Borrowings still represent the category of something alien, because they require additional commentary. There are other examples of borrowed vocabulary in the text; for the most part these are intangible concepts, terms of the humanitarian sphere that have no Czech equivalents (logický, ironie, infinitiv, symboly, etc.). In the text they are not marked in any way, and additional comments on them are not found.

\section{Intertextuality}

The next area that reveals in the texts of Linhartová her style-forming potential is intertextuality. Following the French researcher N. Piegay-Gros, we will distinguish the notions of intertextuality as a device for including one text into another and intertext as a set of texts reflected in this work (Piegay-Gros, 2008: 48-49). In Linhartová's texts there are various intertextual forms: quotations, reminiscences, allusions, that is, from the most accurate to the most veiled form of reference to a different text. Yu. M. Lotman calls ,the implicit" the defining property of allusion (Lotman, 1981: 38) which again means the need for a highly erudite reader to decode all possible meanings.

All the intertextual insertions that we were able to identify in the reviewed texts can be divided into three groups: biblical intertext, mythological intertext and literary intertext. It is noteworthy that the last category of intertexts is found only in the chronologically first text, and only within it there is a reference to the Czech literary tradition: the texts of Vladimír Holan, František Halas are quoted, Karel Hynek Mácha and Richard Weiner are mentioned. In the mythological intertext, contrary to our expectations, the author's national identity does not reflect in any way.

Quite a large number of references to the Bible and ancient mythology (Orpheus and Eurydice, the thread of Ariadne, the war of frogs and mice) speak of Linhartová's aspiration to write her texts into the common European tradition, thus realizing the cultural function.

From the point of view of style formation, these components are important, since they again represent the embodiment of the principle of free association and serve as such components of the text as can give impetus to the appearance of the next link in the text chain. This is perfectly illustrated by the example given above with the Tower of Babel, when, through the introduction of a component of a common European cultural code, a text is built, and certain language means are selected.

In the case of the texts under consideration, it is also worth referring to the classification of I.V. Arnold, who divides the intertext into external (reference to the text of another author) and internal (inclusion into the text of inserted elements written by the author himself, i.e. letters, diaries, etc.) (Arnold, 1999: 422). In the text "Meziprůzkum nejblíž uplynulého" we find a large number of quotations from letters addressed to the narrating subject, retelling his conversations with other people, as well as quoting himself. In the text itself there is a special reference to the function of the quotations given by the narrator. He himself explains it this way: 
Téměř každou větou se dotýkám nějakého dřivějšiho setkáni, nějakého rozhovoru. Každý takový rozhovor vytvář́ jeden zákrut tohoto myšlenkového postupu-mohu sledovat téměr názorně vrcholky jednotlivých prohloubení, které mi zůstaly z různých setkání... Vrcholky těchto prüniků tvoři obrys mé pritomné podoby-nerovný, stěži prehledný obrys, který sleduji, přejižděje ho prstem. (Meziprůzkum nejblíž uplynulého, p. 159) [With almost every sentence I touch some kind of past meeting, some kind of conversation. - Each such conversation creates one round of this stream of thoughts - I can almost visually watch the tops of the solitary depressions which remained with me from past meetings... The tops of these crossings create outlines of my current shape-uneven, hardly visible outlines which I study, directing my finger along them]. That is, the internal intertext serves as a means of self-determination of the subject. The narrating subject by means of verbalization of memoirs, other people's words and fixing them in writing creates himself. We can finally find in this text a visual reflection of Linhartová's ideas that language constructs reality, and that a man exists only at the moment of speech.

\section{Conclusion}

In this article, only a part of the observations and conclusions that we were able to draw when reading Linhartová's later Czech texts were summarized. The overall picture is such that the style of the writer changes noticeably from text to text, getting increasingly complicated in the final stage of her creativity. This is symptomatic, because employing more complex and multifaceted forms in its structure eventually led Linhartová to the boundary of the expressiveness of the language, which is why later she abandoned literary work in the Czech language altogether. Linhartová's exit from the surrealist group two years before her emigration is also significant. The influence of ideas of the trend on the work of the writer, based on our observations, is indisputable. Probably, such an approach to writing texts, based on the liberation of consciousness, was a catalyst for the knowledge of the boundaries of language for Linhartová.

\section{References}

Andreev L.G., (2004), Surrealizm. Istorija. Teorija. Praktika, [in Russian: Андреев Л.Г., Сюрреализм. История, Теория, Практика] Moscow.

Anikina T.E. (2012), Zaglavija khudozhestvennogo texta: Nauchnyj doklad, [in Russian: Аникина T.Е., Заглавия художественного текста: Научный доклад.] Saint Petersburg.

Arnold I.V. (1999), Semantika. Stylistika. Intertextualnost: Sbornik statej, [in Russian: Арнольд И.В., Семантика. Стилистика. Интертекстуальность: Сборник статей] Saint Petersburg.

Huizinga J. (1997), Homo ludens. Statji po istorii kultury, [translation from Dutch into Russian: Хёйзинга Й., Homo ludens. Статьи по истории культурь] Moscow.

Lanstyák I. (2000), Kotázke striedania kódov (mad’arského a slovenského jazyka) v komunite Mad'arov na Slovensku // Slovo a slovesnost, № 1, p. 117 [in Slovak]. 
Linhartová V. (1964), Meziprůzkum nejbliž uplynulého. České Budějovice: Krajské nakladatelství [in Czech].

Linhartová V. (1968), Dům daleko, Praha: Mladá fronta [in Czech].

Lotman Y.M. (1981), Text v texte, [in Russian: Лотман Ю.М., Текст в тексте // Труды по знаковым системам. T. XVI / Учен. зап. Тартуского гос. ун-та] Tartu.

Machová S. (2008), Syntax obecné češtiny // Bohemistyka, № 1-4, p. 309-320 [in Czech].

Mareš P. (2003), „,Also: Nazdar!“ Aspekty textové vícejazyčnosti, Praha [in Czech].

Müllerová O. (1994), Mluvený text a jeho syntaktická výstavba. Praha [in Czech].

Piegay-Gros N. (2008). Vvedenie v teoriju intertextualnosti [translation from French into Russian: Пьеге-Гро Н., Введение в теорию интертекстуальности] Moscow.

Pytlík R. (1969), Promluvy a hry Věry Linhartové // Česká literatura, № 17, p. 159-178 [in Czech].

Sedláček M. (1986), K základním otázkám interpunkce v češtině // Naše řeč, № 3, p. 121-132 [in Czech].

Tippnerová A. (2014), Permanentní avangarda? Surrealismus v Praze., Praha [translation from German into Czech].

\section{Резюме}

\section{Особенности стилистики сюрреалистской экспериментальной прозы Веры Лингартовой}

В статье описываются стилистические особенности поздней чешскоязычной прозы Веры Лингартовой, которая относится к периоду ее сотрудничества с пражской группой Surrealistická skupina [«Сюрреалистическая группа»] в 1962-1965 гг. Внимание авторов статьи сосредоточено на стилеобразующем потенциале синтаксических конструкций, переключении кодов и интертексте, которые являются частью поэтики писательницы в духе сюрреалистической традиции.

Ключевые слова: чешский сюрреализм, синтаксис, многоязычность, интертекстуальность, Лингартова

\section{Streszczenie \\ Właściwości stylistyki surrealistycznej prozy Very Lingartovej}

Artykuł zawiera opis właściwości stylistycznych późnej czeskojęzycznej prozy Very Lingartovej odnoszącej się do okresu jej współpracy z praską grupą Surrealistická Skupina (Grupa Surrealistyczna) w latach 1962-1965. Autorki artykułu skupiły swą uwagę na potencjale stylowym konstrukcji składniowych, przełączaniu kodów w intertekście, które są częścią poetyki pisarki w duchu tradycji surrealistycznej.

Słowa kluczowe: surrealizm czeski, składnia, wielojęzyczność, intertekstualność, Lingartova 